\title{
Concorrência no mercado portuário de contêineres
}

\author{
Egon Bockmann Moreira
}

Parecer

Ementa: Direito Empresarial. Direito Econômico. Prazo contratual e equilíbrio econômico-financeiro do contrato administrativo. A prorrogação como forma de promover o reequilíbrio. Arrendamento portuário e unificação: autonomia jurídica e econômica.

Sumário: I. O caso concreto e os quesitos apresentados; II. Preservação do equilíbrio econômico-financeiro mediante prorrogação contratual; II.1 A mutabilidade dos contratos de arrendamento portuário; II.2 O regime jurídico das prorrogações contratuais; II.3 O regime jurídico da prorrogação extraordinária; III. A unificação de projetos de arrendamento portuário: natureza e regime jurídico; IV. Conclusão.

\section{O caso concreto e os quesitos apresentados}

1. A Consulente apresentou para exame o caso a seguir descrito, bem como formulou as perguntas que se seguem. Com a consulta, foram trazidos todos os documentos necessários e suficientes ao conhecimento da questão controversa e às respostas aos quesitos formulados.

1.1 A Consulente é operadora portuária, inclusive de contêineres. Em vista da sua expertise, bem como do incentivo institucional das autoridades públicas para que fossem concretizados investimentos no setor portuário, 
a Consulente detectou uma oportunidade em importante porto brasileiro, doravante "Porto" (que, todavia, contava com situação monopolística no setor de contêineres, com sério bottleneck). ${ }^{1}$

O Porto possui demanda compatível com as necessidades de desenvolvimento da região. Contudo, há pontos de estrangulamento que restringem o processo produtivo e geram perdas coletivas. A solução para um desses gargalos foi detectada pela Consulente. A oportunidade exigia a instalação de estrutura compatível com os investimentos, a fim de gerar o respectivo ganho de escala - orientado pelo equilíbrio econômico-financeiro do projeto - e a viabilidade de instalar situação de concorrência no mercado de contêineres (e respectiva armazenagem) do Porto.

Isto é, na medida em que o operador histórico do Porto já era detentor de capacidade operacional extraordinária, bem como havia demanda que a ultrapassava, pouco ou nada eficiente seria a instalação de infraestrutura que não atendesse às necessidades estratégicas nem apresentasse ganhos compatíveis.

1.2 Ocorre que o Porto contava com um terminal retroportuário de aproximadamente $50.000 \mathrm{~m}^{2}$ (doravante "Terminal 1", com termo final do contrato em 2026) e com outro terminal retroportuário alfandegário de aproximadamente $41.000 \mathrm{~m}^{2}$ (doravante "Terminal 2", com termo final do contrato em 2021), cujas instalações eram intermediadas por uma área desocupada (de aproximadamente $20.000 \mathrm{~m}^{2}$ ). Eram dois contratos de arrendamento que tinham vida autônoma, sem se preocupar com a sinergia que poderia advir de sua união.

Muito embora as duas sociedades - diretamente ou por meio de suas controladas - realizassem atividades variadas no setor portuário, fato é que essa fragmentação estrutural impedia que ambos os empreendimentos bem desenvolvessem suas tarefas. A divisão geográfica frustrava os ganhos de escala. Logo, a Consulente passou a cogitar da unificação dos dois contratos de arrendamento (rectius: dos dois projetos de arrendamento portuário).

1 Trata-se de fato incontroverso, conforme consta, dentre outros documentos, em uma das informações transcritas pelo CADE como razão de decidir no acórdão de Ato de Concentração: "Além do Terminal 1 e do Terminal 2, no Porto, só existe o TECON (Terminal de Contêineres), que também presta serviços de armanezagem alfandegada na área primária do porto, mas desde que haja espaço disponível em sua área retroportuária, a qual muitas vezes encontrase congestionada, lotada de cargas, principalmente carga de importação, razão pela qual os importadores/exportadores precisam recorrer a terminais secos (recintos alfandegados) [...] além do TECON, no caso deste porto não existem alternativas economicamente viáveis para os importadores/exportadores" (fl. 337 - numeração CADE; fl. 6 - numeração voto). 
1.3 Como se não bastasse a necessidade de eficiente atendimento à demanda portuária, essa opção técnico-econômica atendia a dispositivos legais e regulamentares. A lei e os regulamentos setoriais incentivam a unificação dos contratos. ${ }^{2}$ A legislação e a autoridade regulatória competente definiram, expressamente, que é de interesse público a unificação de contratos de arrendamento portuário.

Isto é, além de cumprir o princípio da eficiência, a unificação destinava-se a atender ao princípio da legalidade e ao interesse público primário. Não se tratava, portanto, de escolha discricionária, mas sim de específica diretriz aplicável a todo o setor portuário brasileiro.

1.4 Porém, havia área desocupada entre os dois terminais. Foi necessária a expansão de um deles (o Terminal 1), fazendo com que a área contígua fosse incorporada ao empreendimento. Assim, deixariam de existir dois (relativamente) pequenos terminais independentes, intermediados por área imprestável, e poderia se instalar um só empreendimento unificado.

Desde que o Terminal 1 passou a contar com área maior (e contígua à do Terminal 2), alterou-se a visão estrutural do projeto. Eles estavam fisicamente unidos - faltava apenas a sua unificação jurídico-empresarial (societária, regulatória e concorrencial).

1.5 Ou seja, na justa medida em que originalmente se tratava de duas sociedades empresariais arrendatárias, detentoras de dois contratos com o Porto, supervisionados pela mesma agência reguladora (ANTAQ), era necessária a prévia aprovação da fusão dos empreendimentos (e respectivos contratos de arrendamento). Demais disso, fazia-se necessária a aprovação por parte da autoridade concorrencial (a aquisição submeteu-se ao art. 54, §3으, da então vigente Lei 8.884/1994; hoje, Lei 12.529/2011).

Todos os pedidos (participação societária; sucessão nos contratos; unificação dos projetos) foram tempestivamente submetidos às autoridades

2 Trata-se da diretriz traçada pela Resolução ANTAQ 2.240/2011 (Aprova a norma que regula a exploração de áreas e instalações portuárias sob gestão das administrações portuárias no âmbito dos portos organizados), cujo art. 84 previu expressamente que: "§2º No caso da exploração de áreas e instalações portuárias operacionais e não operacionais sob o regime de arrendamento, além da adaptação às disposições contidas nesta Norma, a regularização prevista no caput deverá contemplar modificações objetivando, dentre outras: a) a preservação do equilíbrio econômico-financeiro do contrato, nos termos do art. 65 da Lei no 8.666, de 21 de junho de 1993; b) a inclusão de cláusulas essenciais no contrato; c) o ajuste do objeto de exploração portuária, quando pleiteado pela arrendatária, observada a regulamentação específica expedida pela ANTAQ; d) a unificação de contratos de arrendamento independentes celebrados entre a Administração do Porto e um mesmo arrendatário; e e) a possibilidade de ampliação da área explorada, se for o caso". (g.n.) 
competentes, de modo transparente e colaborativo, instruídos com os documentos e estudos necessários e suficientes ao seu conhecimento (e provimento). 2. Como à época vigia a hoje antiga Lei de Portos (Lei 8.630/1993), no curso do processo revogada pela Medida Provisória 595/2012 (convertida na Lei 12.815/2013 - a atual Lei de Portos), em combinação com a redação original da Lei da ANTAQ (Lei 10.233/2001), ${ }^{3}$ foram feitas as necessárias consultas aos órgãos e entidades competentes e obtidas as respectivas aprovações. Em suma:

a) Consulta do Terminal 1 ao Porto - que, em dezembro de (...), comunicou que havia deliberado "no sentido de autorizar a transferência do controle societário dessa empresa a Consulente";

b) Consulta à ANTAQ, que autorizou "a ampliação do arrendamento de titularidade do Terminal 1, em $20.000 \mathrm{~m}^{2}$, em área contígua, em conformidade com o contrato particular de arrendamento de área no Complexo Industrial Portuário" e determinou à autoridade portuária que apresentasse as "medidas tendentes à unificação dos contratos";

c) Consulta à Secretaria de Acompanhamento Econômico - SEAE; à Secretaria de Direito Econômico - SDE e ao Conselho Administrativo de Defesa Econômica - CADE - que, em maio de (...), aprovou a operação, desde que alteradas duas das cláusulas dos contratos de compra e venda de ações/quotas;

d) Aprovação, pela ANTAQ, da transferência do controle societário do Terminal 1 e do Terminal 2 para a ora Consulente;

e) Aprovação, pela ANTAQ, da unificação dos contratos de arrendamento.

Todos estes atos e resoluções foram precedidos, a partir do ano de (...), de extensos e minuciosos estudos técnicos, econômicos e jurídicos. Instadas a se manifestar sobre todos e cada um dos momentos do processo de unificação dos contratos de arrendamento portuário as autoridades competentes os aprovaram e, expressamente, os incentivaram - emanando ordens para que fossem desenvolvidas as medidas tendentes a essa unificação.

\footnotetext{
3 Isso ao lado do Decreto 6.620/2008 (Dispõe sobre políticas e diretrizes para o desenvolvimento e o fomento do setor de portos e terminais portuários de competência da Secretaria Especial de Portos da Presidência da República, disciplina a concessão de portos, o arrendamento e a autorização de instalações portuárias marítimas), este hoje revogado pelo Decreto 8.033/2013 (Regulamenta o disposto na Lei no 12.815, de 5 de junho de 2013, e as demais disposições legais que regulam a exploração de portos organizados e de instalações portuárias).
} 
Ademais, em vista da previsão do art. 12, inc. III, da Medida Provisória 595/2012 (hoje, art. 16, inc. III, da Lei 12.815/2013) ${ }^{4}$ mesmo depois de aprovado, a ANTAQ determinou que o processo fosse submetido à Secretaria de Portos da Presidência da República - SEP.

3. A análise objetiva do caso concreto comprova que as autoridades administrativas competentes fizeram nascer a confiança legítima de que o projeto tal como incentivado pelas normas regulamentares e submetido aos órgãos e entidades públicas - era perfeito, válido e eficaz.

O que exigiu o segundo passo: os investimentos iniciais - que vão desde a demolição de edificações imprestáveis até a compra de novas empilhadeiras e escâner de contêineres, passando pela construção de novos prédios (e respectiva infraestrutura de telecomunicações e elétrica). Isso sem se falar na reorganização da força de trabalho.

Logo, a Consulente houve de fazer os estudos e dar início aos respectivos aportes de recursos e modificação da infraestrutura dos terminais. Caso contrário, deixaria de aproveitar as oportunidades e desperdiçaria tempo. Hoje, os investimentos ultrapassam a marca dos $\mathrm{R} \$ 25 \mathrm{MM}$ (fato reconhecido pelas autoridades competentes).

4. A situação fática oriunda das manifestações das autoridades competentes implica as seguintes constatações: por um lado, são incontroversas a eficiência,

4 Eis o texto da norma: “Art. 16. Ao poder concedente compete: [...] III - celebrar os contratos de concessão e arrendamento e expedir as autorizações de instalação portuária, devendo a Antaq fiscalizá-los em conformidade com o disposto na Lei no 10.233, de 5 de junho de 2001". A rigor, em momento algum a Lei 12.815/2013 qualifica expressamente a Secretaria Especial de Portos - SEP como "poder concedente" - nem nos dispositivos que tratam da SEP (art. 15, art. 17, inc. XIV e §2º art. 22; art. 25, §3; ; art. 53; art. 64; art. 65 e art. 71 - este, referente a alterações na Lei 10.233/2001); nem naqueles que tratam do "poder concedente" (art. 5o, incs. XIV e XVI; art. $6^{\circ}, \S \S 1^{\circ}$ a $6^{\circ}$; art. $10^{\circ}$; art. 12; art. 16; art. 17, $\S 1^{\circ}$, incs. II e XV; art. 19; art. 25; art. $57, \S \S 1^{\circ}$ e $3^{\circ}$; art. 59, par. ún, e art. 71 - este, referente a alterações na Lei 10.233/2001) muito embora estes, às vezes, dissociem a ANTAQ do poder concedente, ao atribuir à agência o dever de cumprir atos e diretrizes elaboradas por ele, bem como o de fiscalizar os contratos que ele celebrar. Mas também fazem confusão ao indicar que o "poder concedente" disciplinará a "pré-qualificação do operador portuário", mas no caso de indeferimento do pedido o recurso deverá ser "dirigido à Secretaria Especial de Portos da Presidência da República" (art. 25, caput e $\S^{\circ}$ ) - o que dissocia as pessoas "poder concedente" e SEP. Quem diz, expressamente e $a b$ ovo, que o "poder concedente será exercido por intermédio da Secretaria Especial de Portos da Presidência da República" é o parágrafo único do art. $1^{\circ}$ do Decreto 8.033/2013. O que resta saber é se a competência regulamentar autoriza essa estatuição, bem como a alteração, ope legis (mas em ato de nível infralegal), do polo ativo dos contratos de concessão e de arrendamento. Para os contratos futuros, o problema não se põe; mas, para os passados, é bastante complicada a "substituição contratual" via decreto (sobretudo se o poder concedente original não foi extinto - isto é, não se trata de sucessão, mas de substituição regulamentar unilateral). 
a quebra do bottleneck que dificulta o desenvolvimento do Porto, o ganho de escala, a majoração dos investimentos e a necessidade de ganhos de sinergia.

Por outro, não se está diante de dois equilíbrios econômico-financeiros, mas de um só: aquele que retrata o contrato/projeto de arrendamento unificado. Quando se fala em unificação, não mais existem dois contratos. E com tal unificação, o interesse público primário está sendo prestigiado ao máximo não só no presente (melhoria na prestação do serviço, aprimoramento da infraestrutura de bens públicos e incremento na receita a ser gerada aos cofres da administração portuária), mas, sobretudo, no futuro (uma coisa são os bens reversíveis fragmentados, oriundos de dois contratos parciais que multiplicam custos; outra é o terminal com $91.000 \mathrm{~m}^{2}$ a ser revertido para a administração portuária).

5. Por fim, há que se destacar que ao longo da execução contratual, desequilíbrios econômico-financeiros surgiram em prejuízo da Consulente. Tanto a demora na aprovação quanto outros fatos imputados diretamente ao Poder Concedente trouxeram impacto direto na equação que confere segurança jurídica do contrato administrativo.

6. Neste cenário, surgiu dúvida/oposição das doutas procuradorias jurídicas da ANTAQ e da Secretaria de Portos da Presidência da República - SEP. As ponderações feitas na ANTAQ foram objeto de análise no relatório/voto que deu origem à Resolução da ANTAQ. Todavia, foram renovadas e persistiram em aberto nas razões consignadas no respeitável parecer da procuradoria da SEP.

Isso, muito embora - tal como mencionado expressamente pelo Parecer da ANTAQ e da Secretaria de Portos da Presidência da República - SEP o Tribunal de Contas da União - TCU já tenha decisões no sentido de se admitir a prorrogação extraordinária, em razão das peculiaridades de cada caso concreto.

Ciente de tal manifestação, a Consulente apresentou formalmente suas razões à SEP, o que gerou parecer jurídico aprovando o pedido administrativo, mas sugerindo que ele fosse submetido ao TCU. Daí, ao que se infere, a instalação da consulta, dirigida pela SEP ao TCU, que trata exatamente da questão acima narrada, bem como da possibilidade de emprego de prorrogação extraordinária do contrato para reestabelecer seu equilíbrio econômico-financeiro, ainda que em termos abstratos.

De igual modo, daí resulta a mais plena legitimidade e legalidade da participação da ora Consulente no processo de consulta ora em trâmite no TCU. 
7. Em vista dessa controvérsia, a Consulente formula os seguintes quesitos:

1. A prorrogação extraordinária do prazo contratual é medida cabível para fins de reequilíbrio econômico-financeiro?

2. Em caso afirmativo, encontraria ela os mesmos limites afetos às prorrogações ordinárias?

3. Seria válida, perante o Ordenamento Jurídico brasileiro, a unificação dos contatos de arrendamento portuário?

4. Uma vez unificados os contratos de arrendamento portuário, como se avaliar a validade do equilíbrio econômico-financeiro do pacto e do papel do prazo contratual para a sua configuração?

Passo ao exame do caso concreto.

\section{Preservação do equilíbrio econômico-financeiro mediante prorrogação contratual}

8. Como se sabe, à Administração Pública é imputado o dever - constitucional e legal - de manutenção do equilíbrio econômico-financeiro do contrato de modo simultâneo à constatação de seu desequilíbrio. A Constituição prescreve que devem ser, sempre e incondicionalmente, "mantidas as condições efetivas da proposta" (art. 37, inc. XXI) - e o verbo manter revela que pouco ou nada adianta o reequilíbrio a posteriori, pois postergar o reequilíbrio só significa agravar o desequilíbrio (leia-se os prejuízos endocontratuais). O dever de reequilíbrio do contrato simplesmente não pode esperar.

Caso o desequilíbrio econômico-financeiro não seja corrigido em sua raiz, logo no instante de seu nascimento, ele gerará impacto ao interno do contrato. Uma vez subvertidas as "condições da proposta", ipso facto instala-se o dever administrativo de conformar o contrato e promover a sua estabilidade. Isso porque, salvo hipóteses excepcionais (sobretudo em contratos de curto prazo), o desequilíbrio tende a crescer exponencialmente.

9. A hipótese tradicional de recomposição do equilíbrio econômico-financeiro é a pecuniária. A Administração desembolsa o valor que importou o desequilíbrio - e o contrato volta a funcionar tal como originalmente configurado. O desembolso de verbas públicas presta-se a manter a estabilidade econômicofinanceira contratual e assim cumprir o dever imposto pela Constituição brasileira. 
Porém, se atentarmos para essa ordem de soluções, é fácil a constatação de que elas têm afinidade com contratos de desembolso (tal como as empreitadas de obras e serviços). Afinal de contas, tais contratos foram originalmente estruturados por meio de prestações pré-configuradas desde o edital (execução de obras e serviços), com quantificação monetária exata. Mais: a lógica de tais pactos é a do desembolso de verbas públicas, em contrapartida à boa execução do escopo contratual (contratos bilaterais, sinalagmáticos e comutativos). Configuração que se afasta dos contratos públicos de longo prazo dentre eles, o arrendamento portuário.

Para os contratos públicos de longo prazo, é diversa a rationale do vínculo intersubjetivo Administração (concedente) e particular (concessionário arrendatário), inclusive quanto ao seu equilíbrio econômico-financeiro. ${ }^{5}$ Demais disso e salvo as hipóteses de concessões administrativas e patrocinadas (Lei 11.079/2004), não existem desembolsos pré-programados de verbas orçamentárias. Ao contrário: é um terceiro, avesso à relação-mãe, quem gera a receita contratual: o usuário torna-se, ope legis e ope contractus, o principal pagador dos bens e serviços prestados (a ele, ao Poder Público e a toda a comunidade). ${ }^{6}$ Por conseguinte, o reequilíbrio de contratos administrativo de longo prazo - dentre eles, o arrendamento portuário - exige maiores reflexões, inclusive quanto à respectiva mutabilidade.

\section{II.1 A mutabilidade dos contratos de arrendamento portuário}

10. Os temas acima desenvolvidos permitem que se trate de algo essencial à compreensão da dinâmica dos contratos de arrendamento portuário. Tais contratos necessitam ter prestigiada a respectiva mutabilidade para que consigam sobreviver no longo prazo. ${ }^{7}$ Istoé, eles não podem ser compreendidos

5 Cf. Egon Bockmann Moreira. Equilíbrio econômico-financeiro em contratos administrativos de longo prazo. Revista do TRF da 4a Região 1/169-179. Porto Alegre: EMAGIS TRF4, out. 2004.

6 Sobre a configuração da relação jurídico-concessionária e respectiva multiplicidade de contratos (relação jurídica unitária e complexa), v. Egon Bockmann Moreira. Direito das concessões de serviço público. São Paulo: Malheiros, 2010. p. 89-102.

7 O tema da mutabilidade como forma de garantir a segurança jurídica não é exclusivo dos contratos administrativos de longo prazo - mas se irradia por amplo espectro de situações. Basta pensar na "mutabilidade constitucional" - o texto a persistir, mas a norma a sofrer mutações substanciais - para se confirmar a tese. Sobre os vários ângulos desse fenômeno contemporâneo, v. Georg Jellinek. Reforma y mutación de la Constitución. Trad. C. Föster. Madri: Centro de Estudios Constitucionales, 1991, passim; Anna Cândida da Cunha Ferraz. Processos informais de mudança da Constituição. São Paulo: Max Limonad, 1986; Gilmar Ferreira Mendes. 
como imutáveis, sob pena de serem conduzidos à própria ruptura e extinção (com todas as consequências gravosas daí advindas: prejuízos e dever de indenização por parte do concedente; ausência na prestação do serviço de interesse público; incremento dos riscos dos respectivos setores etc.).

De mais a mais, como em todos os contratos que envolvem projeções futuras de longo prazo, os arrendamentos portuários são típicos contratos incompletos - aqueles que "têm a essência qualificada por elementos naturalmente variáveis: os fatos a serem enfrentados quando de sua execução; o comportamento do concedente, concessionário e usuários; as relações multilaterais; a dependência a fatores exógenos; o longo prazo; as variações mercadológicas globais etc." ${ }^{8}$ Como nas demais situações fáticas de longo prazo, aqui o futuro é definido de maneira precária.

Mas, exatamente o que se quer dizer com isso? Que tais contratos de longo prazo sempre se submetem a intensos desafios factuais futuros. Por mais bem elaborados que sejam o edital e o contrato administrativo, não há como escapar de sua natural incompletude. Esse característico é todo próprio dos atos e contratos disciplinados pelo Direito Administrativo da Economia, sobretudo porque disciplinam relações socioeconômicas tão sensíveis (portos, água, energia, transportes, telecomunicações etc.), que congregam grande volume de investimentos e são submetidas a negócios jurídico-administrativos dirigidos ao futuro (que possuem metas de performance; riscos quantificáveis; incertezas de impossível previsão; intensas demandas sociopolíticas etc.).

O papel do Senado Federal no controle de constitucionalidade: um caso clássico de mutação constitucional. Revista de Informação Legislativa, 162/149-168. Brasília: Senado Federal, abr.jun. 2004; Egon Bockmann Moreira e Heloisa Conrado Caggiano. O poder normativo das agências reguladoras na jurisprudência do STF: mutação constitucional do princípio da legalidade? In: Floriano de Azevedo Marques Neto; Fernando Dias Menezes de Almeida; Irene Patrícia Nohara e Thiago Marrara (Org.). Direito e Administração Pública: Estudos em Homenagem a Maria Sylvia Zanella Di Pietro. São Paulo: Atlas, 2013. p. 529-547; Egon Bockmann Moreira. Contratos públicos de longo prazo, mutações e segurança jurídica. In: Rafael Fernandéz Acevedo e Patricia Valcárcel Fernández (Org.). La Contratación Pública a Debate: Presente y Futuro. Madri: Civitas, 2014. p. 507-520; Egon Bockmann Moreira. O contrato administrativo como instrumento de governo. In: Pedro Gonçalves (Org.). Estudos de contratação pública - IV. Coimbra: Coimbra Ed., 2013. p. 5-18.

8 Egon Bockmann Moreira. Direito das concessões de serviço público. São Paulo: Malheiros Editores, 2010. p. 115. Ampliar em: Uinie Caminha e Juliana Cardoso Lima. Contrato incompleto: uma perspectiva entre direito e economia para contratos de longo termo. São Paulo: Revista Direito GV 10(1)/162, jan./jun. 2014. Disponível em: <http://direitosp.fgv.br/sites/direitosp. fgv.br/files/artigo-Edicao-revista/07-rev19_155-200_-_uinie_caminha.pdf $>$. Acesso em: 9 dez. 2015; Fernando Araújo. Teoria económica dos contratos. Coimbra: Almedina, 2007. p. 147-189; Armando Castellar Pinheiro e Jairo Saddi. Direito, economia e mercados. Rio de Janeiro: Elsevier, 2005. p. 117-120. 
Em específico, o longo prazo impede que se tenha a pretensão de que o contrato de arrendamento portuário seja, de antemão, tido por completo e estático. Mesmo porque é mais eficiente que seja mesmo incompleto. Pretender a certeza e a imutabilidade dos desafios futuros é uma ilusão que apenas dificulta a execução de contratos submetidos a largos períodos. Em setores tão sensíveis a demandas populares, inovações tecnológicas e variações de demandas globais, a garantia da mutação regulatória reforça a segurança jurídica.

11. Pois é precisamente isso o que se dá em contratos de arrendamento portuário, cuja execução exige conhecimento técnico, harmonia, ritmo, perseverança e equilíbrio durante décadas. Trata-se da exata compreensão esposada por Giovanna Mayer que, citando Floriano de Azevedo Marques Neto e Fábio Barbalho Leite, destaca a mutabilidade dos contratos de arrendamento portuário:

Como mencionado, o setor portuário trabalha com recursos escassos. Melhorar a eficiência do uso desses recursos é medida de rigor. Por conta disso, admitir a imutabilidade contratual é o mesmo que compactuar com a perpetuação de sistemas de logística e de tecnologia que não atendem à prestação do serviço. É correto, pois, afirmar que a alteração dos contratos de arrendamento "não é uma superveniência remota e improvável, não requer, pois, um fato especialmente inesperado". Para haver a alteração, basta que haja um fundamento razoável que a justifique, como o aumento da demanda de determinado serviço portuário, por exemplo. ${ }^{9}$

Ocorre que, conforme mencionado na abertura deste parecer, está concretamente configurado e provado que existe fundamento razoável que peculiariza e justifica esta específica mutabilidade contratual. Isto é, desequilíbrios econômico-financeiros também configuram fundamento - legais e legítimos - a justificar mudanças contratuais. Isso para estabilizar o pacto, a fim de imunizá-lo das vicissitudes pretéritas e criar condições para que a prorrogação possa consolidar vantagens ao interesse público, ao Consulente e, sobretudo, aos usuários.

9 Notas sobre o regime dos portos brasileiros. In: Egon Bockmann Moreira (Coord.). Portos e seus regimes jurídicos. Belo Horizonte: Fórum, 2014. p. 108. 
Em outras palavras, a legislação autoriza - senão determina - específicas modificações endocontratuais como um dos meios juridicamente adequados ao restabelecimento do equilíbrio econômico-financeiro do arrendamento em análise. Porém e verticalizando a questão, como pode se tornar concreta a mutação contratual para fins de manutenção de seu equilíbrio ou para eventual reequilíbrio? Quais são as alternativas fornecidas pelo ordenamento jurídico brasileiro?

12. O arrendamento portuário corresponde a forma descentralizada de prestação de serviço público, que se cristaliza através de contrato administrativo. Caso haja desequilíbrios, deve a Administração Pública indenizar a exata medida do ônus experimentado ou perpetrar alteração contratual em variável que componha a remuneração do contrato e seja capaz de colocá-lo na situação econômica e financeira inicialmente preconizada. ${ }^{10}$

Os fatores passíveis de mutação contratual para fim de manutenção do equilíbrio ou para reequilíbrio são vários, a depender da configuração fática e desenvolvimento do respectivo contrato. Pode-se falar em aumento das tarifas, do aumento da base pagante, da minoração de investimentos previstos e da prorrogação de prazo contratual. Todas estas alternativas são amplamente acolhidas pelo ordenamento jurídico brasileiro, inclusive em sede constitucional.

O que mais nos interessa neste parecer é a prorrogação contratual e seu regime jurídico.

\section{II.2 O regime jurídico das prorrogações contratuais}

13. Antes de adentrar o tema das prorrogações para fins de reequilíbrio, faz-se necessário pontuar que o regime das dilações de prazos contratuais compreende, no âmbito dos contratos administrativos, duas hipóteses distintas: (i) as previstas no instrumento e sujeitas aos critérios de avaliação do interesse público posto à guarda da Administração e (ii) as decorrentes da necessidade de reequilibrar a equação econômico-financeira do contrato.

10 De acordo com Luiz Roberto Barroso: “Em tese, um incremento de custo, resultado de uma alteração legítima do objeto contratual, pode ser compensado pela alteração proporcional de qualquer (ou quaisquer) dos elementos que compõem a receita auferida pelo concessionário" (Concessão rodoviária. alterações no objeto do contrato: acrescimentos de obras novas a pedido do poder público. Restabelecimento do equilíbrio econômico-financeiro do contrato. Possibilidades e limites. Disponível em: <http://luisrobertobarroso.com.br/wp-content/themes/LRB/pdf/concessao_ rodoviaria.pdf $>$. Acesso em: 16 dez. 2015). 
O tema é elucidado por Celso Antônio Bandeira de Mello, ao asseverar que:

Cumpre desde logo notar que são situações claramente distintas as de prorrogações contratuais efetuadas por simples convicção da conveniência e oportunidade administrativa de extensão de seu prazo, (diante, sobretudo, do bom desempenho do concessionário e do interesse de ambos na continuidade daquele vínculo) das quais sejam efetuadas tendo em vista a sustentação do equilíbrio econômico-financeiro da relação.

Na primeira hipótese, nada há, do ponto de vista jurídico, que incite o Estado à prorrogação. Questões de conveniência que o atraiam a tanto não se confundem com reclamos jurídicos que o levem a dilatar o prazo contratualmente previsto e estipulado. [...]

Não é esta, contudo, a situação que se porá quando a prorrogação constitui-se em medida assecuratória do equilíbrio econômico-financeiro - direito do concessionário ao qual a Administração não teria como se evadir - sem, contudo, acarretar para o usuário o dispêndio suplementar causado pelo incremento tarifário e sem implicar ônus algum para o Poder Público. [...]

Assim, não há duvidar que, embora inexistindo na lei, no edital ou no contrato, explícita contemplação de prorrogação contratual para atender à finalidade mencionada, esta, sem a menor dúvida ou entredúvida, é perfeitamente cabível. Ou seja: dita prorrogação independe de previsão legal ou contratual. ${ }^{11}$

Note-se que o regime das prorrogações inerentes ao reequilíbrio do contrato não equivale àquele próprio da renovação (eventualmente prevista pelo próprio instrumento). E não só porque aquele independe de previsões contratuais, na medida em que visa a corrigir uma situação anômala, mas sim porque a prorrogação ordinária tende a ensejar desequilíbrios, enquanto a prorrogação extraordinária presta-se a remediar tais desequilíbrios, como nos explica Floriano de Azevedo Marques Neto:

11 Parecer. In: A. C. Carvalho (Org.). Contratos de concessão de rodovias: artigos, decisões e pareceres jurídicos. São Paulo: Ed. MP, 2009. p. 57, g.n. 
A necessidade de definição de prazo para vigência da concessão nos remete ao tema da prorrogação do prazo concessório. Diga-se desde logo que a prorrogação não se confunde com a extensão do prazo para fins de reequilíbrio, nem com a devolução do prazo de delegação diante de situações que tenham impedido a regular fluência do prazo inicial. Prorrogação é a previsão de um novo prazo de concessão que projeta o plexo de direitos e obrigações subjacentes a ela para um novo período, igual ou inferior ao inicial. Ela é, em si, um fator de desequilíbrio contratual, e não de reequilíbrio. (...) Daí ser adequado que a prorrogação coincida com uma recomposição do equilíbrio econômico-financeiro inicial, incluindo-se novos aportes, incrementando obrigações ou exigindo contrapartidas. Isso, insisto, não autoriza a novação completa da concessão ou a ampliação do seu objeto e deve vir, desde o início, com suas premissas e procedimentos delimitados desde o início no contrato que dá ensejo a concessão.

Extensão de prazo para fins de reequilíbrio é o inverso da prorrogação. Aqui ocorre que, por qualquer circunstância, o balanço contratual não pode ser atingido, exigindo sua recomposição. Nesse caso, uma das hipóteses de recomposição do equilíbrio original é a extensão de prazo, sendo, efetivamente, o prazo de concessão um elemento da equação econômica (a exploração da utilidade pública por $\mathrm{n}$ anos é menos vantajosa que a exploração do mesmo objeto por $n+x$ anos). A extensão de prazo para fins de reequilíbrio, ademais, pode ter lugar mesmo em contratos que não projetam a prorrogação ou que a vedem, pois com ela não se confunde. ${ }^{12}$

Por essa razão, a prorrogação extraordinária decorre de dever da Administração - e não de mera faculdade, tal como nas prorrogações ordinárias. Nesse sentido, aliás, o juspublicista português Lino Torgal discorre acerca das chamadas "prorrogações corretoras", destinadas a reequilibrar contratos administrativos:

(...) o que agora está em causa é uma medida compensatória, por intermédio da qual intenta a Administração, por via indirecta - através do alongamento do prazo do contrato - e segundo determinada

12 Concessões. Belo Horizonte: Fórum, 2015. p. 167-168. 
proporção, ressarcir o concessionário do prejuízo adveniente da quebra do equilíbrio em que o contrato originalmente repousava. Dogmaticamente, a prorrogação do prazo do contrato, com este novo fundamento, não traduz já o exercício de uma faculdade por parte da Administração, antes correspondendo a um modo possível de cumprimento do dever jurídico (que sobre aquela impende) de corrigir o desequilíbrio verificado na economia da concessão. ${ }^{13}$

Por conseguinte, é nítido que as prorrogações que visam a reparar a economia do contrato administrativo são medidas postas à disposição da Administração Pública, independentemente das previsões contratuais ordinárias, destinadas a dar cumprimento ao dever legal de compensar o particular (claramente estipulado no art. 9o, §4º, da Lei 8.987/1995). Elas exorbitam do contrato e podem ser aplicadas a qualquer tempo e modo desde que haja uma causa que assim o reclame.

14. Esta especial circunstância submete as ditas "prorrogações corretoras" a regime distinto das prorrogações ordinárias. Tal diferença há de ser destacada não só porque tais prorrogações apresentam racionalidade distinta, mas porque são tuteladas por preceitos normativos também distintos, com ratio diversa.

As prescrições normativas aplicáveis em casos de prorrogação ordinária não se aplicam aos casos em que se cogita da prorrogação contratual como modo de restabelecer a relação originária havida entre encargos e bônus. Inclusive, quanto à possibilidade de se extrapolar o prazo máximo previsto para renovação com vistas a reparar a economia do contrato, anotou Lino Torgal que:

(...) a sua ratio [dos preceitos que fixam prazo máximo para renovação] - evitar que uma determinada actividade pública fique concedida por um tempo demasiado longo - não veda a possibilidade de, perfilando-se razões materiais neste sentido ( $v . g$. ., a necessidade de assegurar a reposição do equilíbrio financeiro da concessão), se efectuar a prorrogação do prazo do contrato em termos que acarretem a ultrapassagem do limite máximo indicado por lei. (...)

13 Prorrogação do prazo de obras e de serviços públicos. Revista de Contratos Públicos, 1/232, Coimbra: Coimbra Ed., jan./abr. 2011, g.n. 
As mesmas regras [que estipulam prazos máximos] já não impedem, todavia, e à luz do que acima se referiu, a fixação de uma prorrogação de prazos que, em concreto, signifique a continuidade do vínculo além do prazo legalmente fixado. ${ }^{14}$

Reitere-se aqui que a possibilidade de prorrogação extraordinária ou corretora não encontra limites no prazo legalmente fixado para prorrogações ordinárias. São realidades e racionalidades absolutamente distintas. Logo, a lógica norteadora da limitação temporal para tais prorrogações é distinta: enquanto que o eventual limite aplicável à prorrogação ordinária deve observância ao prazo fixado em lei para tanto (ou no contrato), o limite aplicável à prorrogação extraordinária deve observância à razoabilidade e à proporcionalidade, na exata medida do desequilíbrio a que se presta a reequilibrar.

15. Tal percepção gera outra consequência, de especial relevância para o caso em exame: possibilita concluir que a ocorrência de uma prorrogação ordinária não constitui qualquer óbice a posterior prorrogação extraordinária. Ainda que ambas tenham reflexos da dilação do prazo contratual, configuram-se institutos distintos, derivadas de situações diversas, com diferentes hipóteses deflagradoras e perpetradas por razões dessemelhantes - logo, a necessidade de uma prorrogação extraordinária, decorrente de desequilíbrios econômico-financeiros que ponham em risco o projeto, a prestação de serviço e o interesse público, não encontra qualquer óbice em pretérita prorrogação ordinária.

Por isso que as normas pertinentes à prorrogação ordinária não podem ser suscitadas em casos de prorrogação extraordinária, pois se referem tão somente a casos de renovação ordinária dos contratos e não excluem a possibilidade de haver outras renovações que visem a reparar o equilíbrio do vínculo, que se fundam em distintas regras de competência.

16. Por fim, cabe uma última ponderação derivada da distinção entre a ratio da prorrogação ordinária e extraordinária no que respeita à previsão contratual. 16.1 Na prorrogação ordinária, a Administração vale-se da competência discricionária que lhe foi conferida pela legislação para que opte e especifique, no momento da contratação, as condições necessárias para tal renovação contratual. Assim, deve encontrar amparo contratual, seja mediante instrumento que admita a prorrogação (ou que não a vede expressamente).

14 Prorrogação do prazo de obras e de serviços públicos. Revista de Contratos Públicos, 1/260, Coimbra: Coimbra Ed., jan./abr. 2011, g.n. 
Nestes casos, entende-se que a prorrogação ocorrerá na medida em que o contrato esteja equilibrado e todas as obrigações bem adimplidas pelas partes. A prorrogação se justificaria, principalmente, dentre outros fatores, pela economicidade oriunda da ausência de necessidade da instalação do custoso processo de licitação (ou na detecção objetiva de que a eficiência seria prestigiada antes pela prorrogação do que por um novo certame), associado à ausência de interesse da Administração Pública na retomada do serviço para si.

No caso das concessões comuns, a prorrogação do termo final do pacto é cláusula obrigatória (Lei 8.987/1995, artigo 23, inciso XII - cuja leitura admite exceções). A sua implementação requer termo aditivo ao contrato de concessão, devidamente motivado (técnica e juridicamente). Há casos em que a prorrogação, como consignado por Tércio Sampaio Ferraz Junior e Juliano Souza de Albuquerque Maranhão, chega a constituir direito adquirido do concessionário: "o respeito a prazo contratualmente estabelecido, incluindo-se aí o prazo da prorrogação, quando cumpridas as exigências contratuais pelo concessionário, constitui direito adquirido e faz parte da proteção do ato jurídico perfeito e acabado". ${ }^{15}$ Mas a ampliação do prazo não pode implicar outro contrato, que desrespeite o objeto e o conteúdo do original - prorroga-se o mesmo contrato, com apenas as adaptações que deem causa ou resultem da prorrogação.

De qualquer modo, fato é que a perfeição, validade e eficácia do ato de prorrogação ordinária dependem dos respectivos motivos de fato e razões de direito, os quais fundamentarão o ato de competência privativa do Poder Concedente.

16.2 Contudo, as prorrogações extraordinárias não necessitam de qualquer previsão contratual. Na medida em que tais prolongamentos cronológicos decorrem de desequilíbrios contratuais originados por situações imprevistas ao tempo da celebração do instrumento, careceria de fundamento exigir que tais contratos previssem, numerus clausus, mecanismos para tutelar essas situações imprevisíveis. Como bem pontuou o saudoso Antônio Carlos Cintra do Amaral:

15 Separação estrutural entre serviços de telefonia e limites ao poder das agências para alteração de contratos de concessão. RDPE, 8/221. Belo Horizonte: Fórum, out./dez. 2004. No mesmo sentido, Maria D'Assunção Costa e Natália Felipe Lima Bonfim. Prorrogação dos contratos de concessão - aspectos gerais. RDPE, 25/197-210. Belo Horizonte: Fórum, jan./mar. 2009. 
Se o poder concedente optar pela prorrogação do prazo, a fim de assegurar o reequilíbrio contratual, poderá fazê-lo independentemente de constar do contrato cláusula de prorrogação, porque se estará diante de uma situação superveniente, imprevisível e extraordinária, criada no interesse dos usuários a fim de garantir-lhes até o final do contrato a prestação de "serviço adequado". ${ }^{16}$

Tal posicionamento, aliás, encontra respaldo no entendimento da própria ANTAQ que, no Parecer no 47/2012/CARG/PF-ANTAQ/PGF/AGU, reconheceu a possibilidade de "ocorrência de nova prorrogação, não estipulada no contrato/legislação, por conta da necessidade de reequilíbrio da equação econômico-financeira inicial".

17. Assim, mesmo ausente previsão contratual ou legal acerca de tal mutabilidade para fins de reequilíbrio, a necessidade de atualização e adequação de contratos administrativos à realidade em que se inserem, bem como o respeito ao equilíbrio econômico-financeiro, tornam a prorrogação extraordinária conatural à natureza e ao regime jurídico dos contratos administrativos de longo prazo. Mais especificamente, trata-se de cláusula impositiva e implícita aos contratos de arrendamento portuário.

Logo, a prorrogação extraordinária não só independe de previsão contratual, como não encontra limites em quaisquer pretensas vedações contratuais (as quais não podem nem prever nem conter a força dos fatos e as vicissitudes naturais a qualquer contrato de longo prazo). Como anota José Anacleto Abduch Santos, o "efeito disso é que serão inválidas todas as estipulações, contratuais ou legais, destinadas a afastar o direito à reconstrução da equação econômico-financeira" ${ }^{17}$ Isso porque sua previsão é indissociável e inerente a tais contratos: não se está diante de um campo livre de diretrizes legais, mas de terreno revestido pela proteção constitucional ao equilíbrio econômico-financeiro.

18. Por fim, em caráter conclusivo das ideias aventadas, são inegavelmente distintas as prorrogações ditas ordinárias daquelas intituladas extraordinárias, assim como os preceitos normativos que as norteiam. O que se tem é uma prorrogação que independe de previsão legal ou contratual - e, por isso mesmo, que merece reforçado respeito institucional.

6 Concessão de serviço público: novas tendências. São Paulo: Quartier Latin, 2012. p. 29.

17 Contratos de concessão de serviços públicos: equilíbrio econômico-financeiro. Curitiba: Juruá, 2010. p. 148. 


\section{II.3 O regime jurídico da prorrogação extraordinária}

19. Como não poderia deixar de ser, o contrato administrativo de arrendamento portuário é um contrato por prazo. E tal prazo assume dupla função: por um lado, assinala a finitude do pacto; por outro, a sua estabilidade. Ou seja, para o Poder Concedente representa a certeza da data em que deverá retomar os bens e serviços arrendados e, para o arrendatário, a certeza de exercício do objeto do contrato, permitindo assim a projeção dos investimentos e a fruição dos bens.

Veja-se que, enquanto elemento norteador da projeção dos investimentos e da fruição dos bens, o prazo da concessão integra a equação econômico-financeira do contrato - condicionando-a e por ela sendo condicionado. E, como elemento indissociável de tal equação, pode - e deve - ser utilizado como meio de preservar-lhe o equilíbrio.

Isso porque o prazo inicialmente preconizado para o contrato administrativo não fora livremente estipulado pelo Poder Concedente. Não se trata aqui de determinação a bel-prazer da Administração ou do particular, mas resultante de complexos estudos envolvendo engenharia econômico-financeira, capaz de garantir o tempo ideal à amortização dos investimentos então previstos. Assim, tal prazo não deve ser inferior, tampouco superior, àquele necessário ao adequado retorno dos investimentos inicialmente preconizados. 20. Ocorre que não raro, ao longo da execução contratual, o particular se vê impelido a realizar investimentos superiores àqueles originalmente previstos e, diante de tal situação, o prazo inicialmente fixado não mais se mostra adequado a amortizar os desembolsos por ele realizados. Cria-se, assim, situação de desequilíbrio contratual que enseja medidas de reequilíbrio - e aqui se mostra plenamente legítima a adoção de prorrogação extraordinária a fim de proteger o equilíbrio econômico-financeiro do contrato.

Acerca do tema, as palavras de Antônio Carlos Cintra do Amaral mostram-se novamente pertinentes:

O prazo contratual, porém, é dimensionado em função de uma previsão inicial de investimentos necessários, dos custos operacionais e financeiros e da projeção de receita. Em um contrato de longa duração, como costuma ser o contrato de concessão, novos e imprevistos investimentos são efetuados durante sua execução, inclusive na etapa final da concessão, a fim de, como diz a Lei 8.987/95 (art. 36), "garantir a continuidade e atualidade do serviço concedido". Esses investimentos, 
cuja necessidade com frequência se evidencia na segunda metade do prazo da concessão, podem ser insuscetíveis de amortização no restante do prazo estabelecido inicialmente. Se não for garantido à concessionária o retorno da totalidade dos investimentos efetuados, ela certamente não os fará por imposição do poder concedente, com isso prejudicando os usuários, no interesse dos quais o serviço foi concedido. Seria ilusório esperar que ela, como empresa privada, legitimamente vocacionada para o lucro, efetuasse investimentos a que não estivesse obrigada por contrato e que, por força da exiguidade do prazo contratual remanescente, não pudessem sem amortizados em sua totalidade. ${ }^{18}$

Com efeito, a dilação de prazo para fins de reequilíbrio mostra-se legal e legítima. Para que, além de legal, se mostre adequada do ponto de vista prático, basta que justificativas técnicas sejam apresentadas mediante estudos competentes, que consigam demonstrar o diagnóstico do desequilíbrio e, igualmente, a capacidade de a prorrogação promover o reequilíbrio. É necessário comprovar que o serviço público será prestado de maneira adequada e que tanto a Administração quanto os particulares serão beneficiados pela eleição dessa medida. Em outras palavras: há de ser demonstrado o prestígio ao interesse público primário que pautou o projeto de arrendamento portuário, em paralelo ao respeito ao direito público subjetivo ao equilíbrio econômico-financeiro do contrato.

Isso porque a prorrogação do prazo contratual tende não só a importar vantagem adicional ao investidor, capaz de compensar/diluir os investimentos feitos a maior (ou as receitas experimentadas a menor), mas também a mostrar-se capaz de atender à modicidade das tarifas e o interesse público.

21. Tal método de recomposição do equilíbrio, quando cabível, permite a diluição de investimentos no tempo correto à sua amortização. Com isso, não se força tal dissipação em período inferior ao adequado - o que, em última análise, incorreria em tarifas demasiadamente onerosas ao usuário em face de reequilíbrio por intermédio de adequação tarifária.

E, caso a Administração decidisse não repassar tais desequilíbrios ao usuário por intermédio da tarifa, poderia optar por indenizar o investidor. Contudo, mediante a possibilidade de dilação de prazo, questiona-se a

18 Concessão de Serviço Público: novas tendências. São Paulo: Quartier Latin, 2012. p. 25-26. 
adequação da adoção de tal medida - a uma, porque incorreria em majoração de gastos públicos quando estes não necessitariam ocorrer e, a duas, porque a destinação de recursos públicos (escassos) para este fim inviabilizaria sua alocação em outros projetos caros ao interesse público.

Nesse sentido, como bem conclui Antônio Carlos Cintra do Amaral com referência à doutrina de Carmen Lúcia Antunes Rocha:

É possível, portanto, sustentar que a prorrogação do prazo é mais condizente com a concessão, porque nesta todos os investimentos são amortizados pelos efetivos usuários do serviço, nenhum deles pela comunidade difusamente considerada. Como escreve Cármen Lúcia Antunes Rocha (Estudos sobre concessão e permissão de serviço público no direito brasileiro. São Paulo: Saraiva, 1996. p. 139-140):

A remunerabilidade da atividade considerada serviço público, querse dizer, a possibilidade de ser cobrada a sua prestação diretamente do cidadão segundo o uso que dele faça, é característica incluída no rol de serviços públicos suscetíveis de serem prestados por delegação a particular. (grifei) ${ }^{19}$

Nos termos acima indicados e em caráter conclusivo, é a prorrogação extraordinária - essa de ratio e preceitos normativos distintos da prorrogação ordinária - plenamente possível, legal e adequada à persecução do interesse público, sendo mecanismo legítimo para o restabelecimento econômico-financeiro em contratos de arrendamento portuário.

\section{A unificação de projetos de arrendamento portuário: natureza e regime jurídico}

22. Dúvida não pode haver de que o contrato de arrendamento portuário se submete à lógica dos contratos administrativos, que associam a função administrativa à atividade empresarial: esta, para ser desenvolvida pelo particular, há de ser pautada por aquela. Porém, é contrato com natureza jurídica diferenciada, submetido a regime jurídico especial.

19 Concessão de serviço público: novas tendências. São Paulo: Quartier Latin, 2012. p. 28. 
Por meio do contrato dinâmico de arrendamento portuário, o poder concedente cede determinado bem público para investimento e exploração privada - que, em contrapartida, presta os serviços a terceiros e paga específica remuneração à autoridade portuária. De igual modo, o contrato traz consigo a delegação/outorga da execução de específica atividade de interesse público, sob a gestão da pessoa privada. A Administração Pública anuncia que dispõe de bem imóvel, localizado em determinado local, o qual pode, em tese, abrigar específica atividade econômica.

23. Consequentemente, não foi devido a um acaso que a Lei $12.815 / 2013$, lei especial que é, ${ }^{20}$ reportou-se apenas e tão somente por uma vez à Lei 8.666/1993 - para chamar a sua aplicação subsidiária apenas às licitações, ao lado da Lei 12.462/2011 (o RDC). Isto vem expresso no art. 66 da Lei 12.815/2013 - e nenhum outro dispositivo da Lei de Portos trata da LGL (ou do RDC).

Isto é, as Leis 8.666/1993 e 12.462/2011 têm importância secundária, acessória, subsidiária enfim, em relação à Lei 12.815/2013 - e se destinam, única e exclusivamente, a subsidiá-la e/ou a socorrê-la em casos extravagantes referentes ao processo de seleção objetiva da proposta mais vantajosa. Ou seja, só no que respeita às licitações (e não aos contratos), tal como literalmente estabelecido em lei. A previsão é extraordinária - e, como se sabe, as normas especiais devem ser interpretadas restritivamente. ${ }^{21}$

Muito embora pertencentes ao mesmo sistema jurídico, são normas cujas racionalidades são adversas, pois regem situações fáticas absolutamente distintas.

20 Nos termos do art. $1^{\circ}$, $§ 2^{\circ}$, da LINDB (Decreto-Lei 4.657/1942), trata-se de lei especial: “lei nova, que estabeleça disposições gerais ou especiais a par das já existentes, não revoga nem modifica a lei anterior". A Lei 12.815/2013 estabelece normatividade especial e autônoma para determinados contratos administrativos, extraordinária em relação à Lei 8.666/1993 (e a todos os demais diplomas que regem as contratações públicas brasileiras). A norma especial (Lei 12.815/2013) prevalece sobre a norma geral (Lei 8.666/1993) - as situações especiais nela previstas devem ser resolvidas segundo as normas especiais nela positivadas. A Lei 12.815/2013 não pode ser lida com a lente da Lei 8.666/1993. Como, aliás, o STF julgou na ADI 1668, em relação à Lei 9.472/1997 - a Lei Geral de Telecomunicações -, ao excluir de seu âmbito normativo as previsões da Lei 8.666/1993 e demais diplomas pretéritos. Vide, sobretudo, o voto do Min. Nelson Jobim e as ponderações do Min. Sepúlveda Pertence, disponíveis em: <www. stf.jus.br/portal/jurisprudencia/listarJurisprudencia.asp?s1=\%28ADI\%24\%2ESCLA \%2E+E+16 68\%2ENUME\%2E $\% 29+\mathrm{OU}+\% 28 \mathrm{ADI} \% 2 \mathrm{EACMS} \% 2 \mathrm{E}+\mathrm{ADJ}+1668 \% 2 \mathrm{EACMS} \% 2 \mathrm{E} \% 29 \&$ base $=\mathrm{b}$ aseAcordaos>. Acesso em: 10 dez. 2015.

21 Nesse sentido é a jurisprudência do STJ, nos mais diversos casos (v.g., REsp 1044203, Min. Arnaldo Esteves Lima, DJe 16/3/2009; REsp 54.1239, Min. Luiz Fux, DJ 5/6/2006; REsp 605025, Min. Gilson Dipp, DJ 21/11/2005; REsp 41.5705, Min. Luiz Fux, DJ 22/4/2003). 
24. A rigor, isso traz consigo a constatação de que os dias de hoje são caracterizados pelos microssistemas normativos autônomos, cada qual a reger as peculiaridades socioeconômicas dos respectivos setores regulados.

Demais disso, sabe-se que os diplomas constitucionais não contêm palavras supérfluas - e isso também se aplica às competências normativas privativamente atribuídas à União. Se a Constituição expressamente diz que são necessárias normas que disciplinem o "regime dos portos, navegação lacustre, fluvial, marítima, aérea e aeroespacial" (art. 22, inc. X), o intérprete não pode pretender subordinar tal preceito a quaisquer outros, mas deve defender a sua aplicabilidade plena, imediata e autônoma. O Direito Portuário Brasileiro, ramo especial do Direito Administrativo Econômico, possui dignidade e estatura constitucionais, portanto.

O que vem confirmado com a edição da Lei 12.815/2013.

25. Note-se que a Lei 12.815/2013 é bastante clara nesse sentido, em vários dispositivos (art. 1ㅇ, $\S \S 1^{\circ} \mathrm{e}$ e $3^{\circ}$; art. $5^{\circ}$, incs. II, III, V, IX, X e XI). O que significa dizer que a Lei 12.815/2013, muito embora instaladora de microssistema autônomo, aproxima-se da racionalidade e do escopo da Lei 8.987/1995 (Lei Geral de Concessões) e da Lei 11.079/2004 (Lei de PPPs). A Lei de Portos trata de variações e tendências a propósito de outorgas, por longo prazo, de bens e serviços públicos a particulares, os quais deverão atender a determinadas obrigações de serviço público e, assim, explorá-los por sua conta e risco, mediante remuneração dos usuários, com regulação da agência administrativa, supervisão fiscalizatória do concedente e paga de preço à autoridade portuária.

Como Flávio Amaral Garcia e Rafael Véras de Freitas lecionam, "o contrato de arrendamento portuário, previsto no Novo Marco Regulatório do Setor Portuário, tem natureza jurídica de uma subconcessão imprópria de serviços públicos, estabelecendo-se uma relação primária, com o concessionário do porto organizado, e outra, secundária, com o Poder Concedente" ${ }^{22} \mathrm{Ou}$, mais especificamente, como escreve Giovanna Mayer, depois de comentar dispositivo da Lei 10.233/2001:

A Lei no $12.815 / 13$ não alterou esse cenário. Os contratos de arrendamento e os de concessão de serviço público portuário possuem as mesmas cláusulas essenciais, o que reforça a ideia de que o arrendamento

22 Portos brasileiros e a nova assimetria regulatória. In: Egon Bockmann Moreira (Coord.). Portos e seus regimes jurídicos. Belo Horizonte: Fórum, 2014. p. 253. 
portuário é 'nova forma contratual administrativa, atípica, híbrida, mista'. Como mencionado acima, as áreas portuárias são escassas e devem ser bem utilizadas. A fixação de padrões de prestação de serviço vai ao encontro dessa premissa. É o novo serviço público que surge, outorgado por formas novas, diferentes da concessão e da autorização. É nessa perspectiva que funciona a relação entre o arrendatário e o arrendante.

$[\ldots]$

Foi essa a linha adotada pela Lei no $12.815 / 13$, que traz encargos semelhantes do concessionário de serviço público ao arrendatário. A única diferença entre eles seria o instrumento de outorga. No mais, há previsão de uma série de direitos e obrigações dos arrendatários, típicas de prestador de serviço público, como a observância da igualdade entre os usuários, da regularidade, continuidade, eficiência, segurança, atualidade, generalidade, cortesia na sua prestação e modicidade de preços. $^{23}$

Em outras palavras, os arrendamentos portuários são projetos de investimento em infraestrutura pública, que envolvem aportes de recursos privados que serão remunerados e amortizados ao longo do prazo contratual.

26. Com lastro na premissa de que os arrendamentos portuários são contratos administrativos extraordinários, é de se perquirir como se dá o desenvolvimento da atividade atribuída ao arrendatário.

Ora, já se viu acima que não se poderia supor que a racionalidade, bem como a natureza e o regime jurídico da atividade desenvolvida para a execução do arrendamento portuário, devesse equivaler à racionalidade, à natureza e ao regime jurídico da execução da empreitada administrativa. É preciso que se investigue, ao interno desse contrato público, qual a natureza e o regime da atividade do arrendatário.

${ }^{23}$ Notas sobre o regime dos portos brasileiros. In: Egon Bockmann Moreira (Coord.). Portos e seus regimes jurídicos. Belo Horizonte: Fórum, 2014. p. 107-108. No mesmo sentido: Floriano de Azevedo Marques Neto. A concessão como instituto do direito administrativo (tese apresentada ao concurso para provimento de cargo de professor titular). São Paulo: Faculdade de Direito/ Universidade de São Paulo, 2013. p. 341-342; Diogo de Figueiredo Moreira Neto. Mutações do direito administrativo. Rio de Janeiro: Renovar, 2000. p. 136 ss.; Suriman Nogueira de Souza Junior. Regulação portuária. São Paulo: Saraiva, 2008. p. 100-113; e Cristiana Maria Melhado Araújo Lima. Regime jurídico dos portos marítimos. São Paulo: Verbatim, 2011. p. 104-114 (com amplas citações de doutrina e jurisprudência). 
Bem vistas as coisas, o regime de execução dos contratos da Lei 12.815/2013 aproxima-se do Direito de Empresa, tal como definido pelo Código Civil. ${ }^{24}$ Assim, a Lei de Portos trata de contratos empresariais dinâmicos, a ser desempenhados por meio da organização individualizada da atividade econômica. Aqui, se dá a outorga de certo bem público correlacionada à de específico serviço público, ambas funcionalizadas em razão do fim a ser atingido (tal como definido em lei, nos regulamentos setoriais e no próprio contrato de arrendamento portuário). Tais bens e serviços são organizados empresarialmente pelo arrendatário, que planeja e implementa atividade econômica toda própria, segundo peculiar configuração econômico-financeira positivada no arrendamento.

Mas atenção: não se trata apenas de concessão de uso de bem público, cuja lógica jurídico-econômica é bastante diversa daquela dos arrendamentos portuários. ${ }^{25}$ Nestes, a outorga do direito real de uso do domínio público é pressuposto para o desenvolvimento do empreendimento relativo à atividade portuária definida no seu regime estatutário (leis e regulamentos) e no próprio contrato administrativo, cuja eficiência e êxito empresarial, ao contrário da clássica concessão de uso de bem público, interessam - e muito - ao poder concedente.

Tal como anotou Eugenio Pinto, nesta ordem de contratos existe nítida "transformação da lógica que inspira o vínculo administrativo", ao fazer com que o lucro empresarial ocorra, mas que ele seja "utilmente empregado para alcançar os objetivos de interesse geral" - isso sem sofrer os efeitos adversos que um controle público totalitário provavelmente geraria. ${ }^{26} \mathrm{~A}$ outorga de ativos e tarefas públicas para desenvolvimento de atividade empresarial pelo particular passa a ser funcionalizada ao cumprimento de determinado escopo de interesse público (tal como definido em lei, em regulamentos e no contrato). 27. Enfim, está-se diante de contrato administrativo que exige o desenvolvimento, estatutariamente definido, de específica atividade empresarial. Ela é

24 “Art. 966. Considera-se empresário quem exerce profissionalmente atividade econômica organizada para a produção ou a circulação de bens ou de serviços."

25 Nesse sentido: Floriano de Azevedo Marques Neto. A concessão como instituto do direito administrativo (tese apresentada ao concurso para provimento de cargo de professor titular). São Paulo: Faculdade de Direito/Universidade de São Paulo, 2013. p. 341-342; Giovanna Mayer. Notas sobre o regime dos portos brasileiros. In: Egon Bockmann Moreira (Coord.). Portos e seus regimes jurídicos. Belo Horizonte: Fórum, 2014. p. 105-107; Rafael Fernández Acevedo. Las concesiones administrativas de dominio público. 2. ed. Madri: Civitas, 2012, passim; Eugenio Pinto. L'economia delle imprese in regime di concessione. Milão: Giuffrè, 1996. p. 18 ss; Egon Bockmann Moreira. A concessão de serviços públicos e os direitos reais administrativos. RT 898/63-78, São Paulo: Ed. RT, 2010.

26 l'economia delle imprese in regime di concessione. Milão: Giuffrè, 1996. p. 22 - tradução livre. 
o núcleo duro dessa ordem de contratos. Por isso se pode dizer que ele constitui o arrendatário como aquela certa pessoa que realizará o empreendimento. $\mathrm{Ou}$, melhor dizendo, cada um dos contratos constitui os respectivos arrendatários, conformando a sua atividade a parâmetros exclusivos, os quais variarão no tempo e no espaço - e, por isso mesmo, poderão demandar esta ou aquela reestruturação societária.

A natureza e o regime jurídico da atividade desenvolvida pela Consulente ao interno do contrato administrativo de arrendamento são regidos pelo art. 966 do Código Civil, parametrizado pela Lei 12.815/2013 (e tornada especificamente densa pela regulação setorial e individualizada no respectivo contrato de arrendamento portuário).

Tendo em vista esse fato jurídico, pode-se abordar a qual regime jurídico se submete a unificação dos contratos de arrendamento portuário do caso em exame.

28. Fixadas as premissas acima, é muito importante que se compreenda que, ao se analisar a unificação de contratos na Lei 12.815/2013, não se está a tratar da mera unificação de pactos de prestação de serviços ou de execução de obras públicas. Ela não pode ser compreendida como a junção de dois negócios jurídicos estáticos, que envolvam o desembolso de verba pública durante curto prazo.

A rigor, quando se fala da união entre dois contratos de arrendamento portuário, está-se a tratar da conjugação de dois projetos empresariais: a junção, numa só, de duas atividades econômicas organizadas para a produção ou a circulação de bens ou de serviços (nos termos do já mencionado art. 966 do Código Civil). Unem-se pessoas e projetos de investimento; não apenas os contratos celebrados com a Administração. Afinal, focar-se exclusivamente nos instrumentos contratuais implica confundir continente com conteúdo: o contrato é mero veículo para possibilitar a exploração de um negócio empresarial definido pela Lei 12.815/2013 (e não um fim em si mesmo). Igualmente por isso, não é exato tratar-se da unificação contratual como algo extravagante ao Direito Administrativo Econômico.

Esta peculiaridade autoriza o exame específico da unificação dos contratos de arrendamento portuário como unificação de sociedades arrendatárias.

29. Foi Ronald Coase quem demonstrou que a pessoa jurídica existe para diminuir os "custos de transação" da respectiva atividade. ${ }^{27}$ As pessoas

27 Sobretudo em "The nature of the firm". In: R. Coase. The firm, the market and the law. Chicago: Univ. of Chicago Press, 1998. p. 33-55. 
jurídicas são contratos com significativa razão econômica, que não pode ser desprezada pelo Direito. ${ }^{28} \mathrm{Ou}$, na definição de Alfredo de Assis Gonçalves Neto:

A sociedade é um negócio jurídico que tem por propósito criar um novo sujeito de direito, distinto das pessoas (ou da pessoa) que o ajustam, capaz de direitos e obrigações na ordem civil, para facilitar o intercâmbio no mundo do direito, interpondo-se entre seus criadores (ou seu criador) e terceiros na realização de negócios. ${ }^{29}$

A mesma ordem de raciocínio "facilitadora de intercâmbios no mundo do direito" se aplica às aquisições, fusões e incorporações de projetos de investimento de longo prazo no setor portuário - ou, em outras palavras, à unificação de contratos de arrendamento portuário. Isto é, ao se analisar um processo de unificação de contratos de arrendamento portuário, está-se a examinar a união de dois projetos de atividade empresarial (e não a mera junção de dois contratos civis clássicos). Está-se diante da união de duas sociedades empresariais.

30. Esta (re)conformação decorre do planejamento empresarial, que vislumbra ganhos oriundos da sinergia entre os contratos, a conferir maior eficiência ao interesse público cometido à autoridade portuária - o que, no caso concreto, já foi reconhecido pela autoridade portuária, pela ANTAQ e pelo CADE. Ou seja, as autoridades competentes firmaram que a unificação atende ao interesse público: que as vantagens serão usufruídas pelo Porto, seus usuários e pela ordem econômica.

A depender de sua estruturação, a unificação de contratos de arrendamento portuário pode se identificar com processos de incorporação ou de fusão. Em todos estes casos, o escopo é o de unir as sociedades - e assim integrar as respectivas organizações sociais e empresariais.

No primeiro deles, a sociedade incorporada deixa automaticamente de existir quando da efetiva incorporação. Já a fusão une duas ou mais sociedades, que deixam de estar presentes para se transformar numa sociedade

\footnotetext{
28 Como de fato não o é, em vista da redação do art. 981 do Código Civil: “Celebram contrato de sociedade as pessoas que reciprocamente se obrigam a contribuir, com bens ou serviços, para o exercício de atividade econômica e a partilha, entre si, dos resultados."

29 Direito de empresa. 5. ed. São Paulo: Ed. RT, 2014. p. 138.
} 
nova, que antes não existia. ${ }^{30}$ Isto é, tanto a incorporação quanto a fusão são modalidades de reorganização societária que implicam a extinção de sociedades (independentemente de liquidação).

Ora, extinta uma sociedade e incorporados todos os seus ativos à outra, torna-se lógica, ipso facto, a constatação de que um dos contratos de arrendamento portuário - o de menor significado econômico-financeiro - foi igualmente extinto (pois agregado ao outro contrato). Seria por demais inconsistente, agredindo a economicidade e a eficiência, pretender-se que a mesma sociedade empresarial firmasse dois contratos de arrendamento, um ao lado do outro, sem conseguir obter os respectivos ganhos de eficiência decorrentes desse fato. Todos perderiam com isso, mas o maior perdedor certamente seria o projeto de desenvolvimento da respectiva infraestrutura portuária.

31. Daí a racionalidade da Resolução ANTAQ 2.240/2011, que estatui como escopo regulamentar a unificação de arrendamentos portuários. Com isso, a agência reguladora, no exercício de sua competência privativa, define que ganhos de eficiência devem ser buscados pelos operadores por meio da unificação e, assim, compartilhados com toda a comunidade portuária.

Daí também a racionalidade dos acórdãos do TCU citados pelo douto Parecer da ANTAQ e da Secretaria de Portos da Presidência da República SEP, a demonstrar que a Corte de Contas "tem aceitado a prorrogação do termo final dos contratos unificados, além do prazo permitido na legislação que rege o tema, em caráter absolutamente excepcional, devido aos investimentos já realizados e as peculiaridades do ajuste". Trata-se dos acórdãos no 2.380 e no 728 , ambos do Plenário. O que confirma que o tema tratado neste parecer já foi prestigiado pelo TCU (inclusive, com a decorrente prorrogação do prazo para além das fronteiras originais).

30 Como preceitua o Código Civil, em seu art. 1.116: “Na incorporação, uma ou várias sociedades são absorvidas por outra, que lhes sucede em todos os direitos e obrigações, devendo todas aprová-la, na forma estabelecida para os respectivos tipos". Como dispõe o art. 1.119 do Código Civil: "A fusão determina a extinção das sociedades que se unem, para formar sociedade nova, que a elas sucederá nos direitos e obrigações". No mesmo sentido são as normas da Lei de S/A (Lei 6.404/1976): "Art. 227. A incorporação é a operação pela qual uma ou mais sociedades são absorvidas por outra, que lhes sucede em todos os direitos e obrigações"; "Art. 228. A fusão é a operação pela qual se unem duas ou mais sociedades para formar sociedade nova, que lhes sucederá em todos os direitos e obrigações". Aprofundar em Alfredo de Assis Gonçalves Neto. Manual das companhias ou sociedades anônimas. 2. ed. São Paulo: Ed. RT, 2010. p. 276-293; José Luiz Bulhões Pedreira. Reorganização: transformação; incorporação, fusão e cisão. In: Alfredo Lamy Filho e José Luiz Bulhões Pedreira (Coord.). Direito das companhias, vol. II. Rio de Janeiro: Forense, 2009. p. 1737-1811; e Modesto Carvalhosa. Comentários à Lei de Sociedades Anônimas, 4. vol., t. I. 3. ed. São Paulo: Saraiva, 2002. p. 257-291. 
32. Não se trata, portanto, da mera soma entre dois contratos administrativos estáticos e de seu equilíbrio econômico-financeiro fechado (oriunda da racionalidade da balança entre encargos e receitas), mas sim do planejamento empresarial que detecta vantagens extraordinárias oriundas da constituição de uma só sociedade empresarial. Trata-se de técnica intensamente prestigiada pelo Direito Administrativo Econômico, que visa, em última análise, a diminuir os custos de transação (e trazer benefícios aos usuários; ao poder concedente e à infraestrutura portuária).

Esta unificação traz ganhos de escala que jamais seriam obtidos individualmente pelos dois contratos de arrendamento portuário: aqui, a união dos dois negócios jurídicos sob a mesma racionalidade empresarial implica vantagens superiores e inalcançáveis autonomamente por cada um dos dois pactos. Isso tanto em termos de eficiência empresarial como em termos de cumprimento ao interesse público primário, que deve visar à excelência na prestação do serviço - sobretudo em casos nodais ao desenvolvimento econômico (regional e nacional).

Constatação que fica bastante reforçada pela análise da ANTAQ no que respeita aos dados técnicos que justificam a economia de escala gerada pela unificação. A autoridade competente decidiu pelo excepcional benefício público oriundo da unificação contratual.

33. Assim e bem vistas as coisas, quando se fala em unificação de contratos de arrendamento portuário, está-se a se tratar apenas de parcela do tema posto a exame.

Isto é, faz-se necessário reiterar e deixar sublinhado que, por meio do arrendamento ao particular, são cometidos o uso e o gozo de determinado bem, gravado pelos deveres de prestação de serviços, mediante pagamento. Também por isso, não é exata a compreensão de que haveria singela união de contratos, que pudesse lhes preservar a autonomia e manter a racionalidade e o prazo de cada um deles. Ora, quando se fala em "unificação de contratos", já não mais se cogita da existência de dois contratos em paralelo, mas de um só, oriundo do amálgama entre os dois anteriores. Está-se diante de três contratos diferentes entre si, portanto, cada qual com as suas peculiaridades (e respectivos equilíbrios econômico-financeiros). Muito embora haja pontos em comum que os congreguem e gerem a respectiva identificação, não se pode tratar da unificação com se ela preservasse os dois projetos de arrendamento subordinando-se o novo contrato unificado às premissas de qualquer um dos dois anteriores. 
Mais ainda: a unificação será regida pela racionalidade oriunda deste amálgama, pelos ganhos de escala dele advindos (já comprovados administrativamente), atendendo-se ao prazo que corresponda ao equilíbrio econômico-financeiro necessário ao empreendimento visto como um todo (que será, quando menos, o do contrato de arrendamento maior).

34. Por fim, fato é que a solução gerou uma série de benefícios públicos.

O interesse público primário cometido às autoridades administrativas só experimentou vantagens: seja pela economia ao Erário conjugada com a melhoria do patrimônio público; seja pelos benefícios diretos aos usuários; seja pelo aumento na arrecadação; seja pela maior eficiência e quebra de pontos de estrangulamento; seja pela futura reversibilidade de um bem com tais características. Estes fatos são incontroversos no relatório, no voto e na resolução emanada pela autoridade pública que detém competência privativa para avaliá-los: a ANTAQ.

Em suma, a unificação de que se cogita neste parecer atende plenamente aos princípios da legalidade, da economicidade e da eficiência. As peculiaridades do caso concreto comprovam tal constatação. Só estes motivos bastariam para a homologação da unificação contratual.

\section{Conclusão}

35. Sintetizando as conclusões expostas acima se tem que as respostas aos quesitos formulados são as seguintes:

1. A prorrogação extraordinária do prazo contratual é medida cabível para fins de reequilíbrio econômico-financeiro?

Sim, de modo especial em contratos administrativos de longo prazo como os de arrendamento portuário. A prorrogação extraordinária permite solução eficiente e proporcional ao desequilíbrio, sem ônus aos cofres públicos.

2. Em caso afirmativo, ela encontraria os mesmos limites afetos às prorrogações ordinárias?

Não. A prorrogação extraordinária, como "prorrogação corretiva" que é, deve respeito ao princípio da proporcionalidade e tem os seus limites definidos pelo próprio desequilíbrio que visa a corrigir. 
3. Seria válida, perante o Ordenamento Jurídico brasileiro, a unificação dos contatos de arrendamento portuário?

Sim. Todo o Ordenamento Jurídico brasileiro, em especial o relativo a portos (leis e regulamentos) prestigiam a validade da unificação de contratos de arrendamento portuário.

4. Uma vez unificados os contratos de arrendamento portuário, como se avaliar a validade do equilíbrio econômico-financeiro do pacto e do papel do prazo contratual para a sua configuração?

A unificação dos contratos instala novo equilíbrio econômicofinanceiro, pautado justamente pelo contrato unificado: é ele, e somente ele, quem pode definir o respectivo prazo contratual.

É o parecer.

Curitiba, 10 de dezembro de 2015.

Egon Bockmann Moreira

Professor de Direito Econômico da Faculdade de Direito e do Programa de Pós-Graduação em Direito da UFPR

Professor visitante da Faculdade de Direito da Universidade de Lisboa

Professor convidado do Centro de Estudos de Direito Público e Regulação da Faculdade de Direito da Universidade de Coimbra Mestre e Doutor em Direito do Estado / Advogado, OAB/PR 14.376 